\title{
Inhibition of chemiluminescent response of olive flounder Paralichthys olivaceus phagocytes by the scuticociliate parasite Uronema marinum
}

\author{
Se Ryun Kwon ${ }^{1}$, Chun Soo Kim ${ }^{1}$, Joon Ki Chung ${ }^{1}$, Hyung Ho Lee ${ }^{2}$, Ki Hong Kim ${ }^{1, *}$ \\ ${ }^{1}$ Department of Aquatic Life Medicine, and ${ }^{2}$ Faculty of Food Science and Biotechnology, Pukyong National University, \\ Pusan 608-737, Korea
}

\begin{abstract}
Experiments were conducted to evaluate the in vitro capacity of the scuticociliatian parasite Uronema marinum to inhibit chemiluminescence (CL) of olive flounder Paralichthys olivaceus phagocytes. Luminol-enhanced CL was used to measure the production of reactive oxygen intermediates (ROIs) generated by respiratory bursts of phagocytes using zymosan as a stimulant. Cytotoxic and antioxidative activities of excretory-secretory (ES) products of the parasite were evaluated as well. Live $U$. marinum and its ES products had a negative and dose-dependent effect on luminolenhanced CL responses of zymosan-stimulated phagocytes of olive flounder. After CL assay, the number of phagocytes showing viability was significantly reduced in the cells incubated with live $U$. marinum at ratios of 2:1 and 1:1 phagocytes:ciliates or ES products with $0.3 \mathrm{mg}$ protein $\mathrm{ml}^{-1}$ compared to controls. Lysis of phagocytes by exposure to ES products was observed also. ES products from $U$. marinum showed considerably high activities of superoxide dismutase (SOD) and catalase. The results of this study suggest that $U$. marinum can protect itself against host's phagocytes mediated oxidative damage by destroying phagocytes and scavenging ROIs.
\end{abstract}

KEY WORDS: Uronema marinum - Paralichthys olivaceus · Phagocytes · Chemiluminescence · Superoxide dismutase $\cdot$ Catalase

\section{INTRODUCTION}

Several scuticociliate species belonging to the genera Uronema, Miamiensis and Philasterides are facultative histophagous parasites in marine fish (Thompson \& Moewus 1964, Cheung et al. 1980, Yoshinaga \& Nakazoe 1993, Dyková \& Figueras 1994, Dragesco et al. 1995, Gill \& Callinan 1997, Munday et al. 1997, Sterud et al. 2000, Iglesias et al. 2001). These ciliates are characterized by their high potential for invading systemically and destroying fish tissues, leading to high mortalities in cultured fishes. In Korea, scuticociliatosis is a serious problem in culturing olive flounder Paralichthys olivaceus, and the causative agent has

*Corresponding author. E-mail:khkim@pknu.ac.kr been identified as Uronema marinum by morphological characteristics (Jee et al. 2001) and homology of 18S rDNA sequence (unpubl. data).

Systemic infection of scuticociliates in fishes is associated with an inflammatory cellular infiltrate consisting of macrophages, lymphocytes and granulocytes at the site of infection (Munday et al. 1997, Sterud et al. 2000, Iglesias et al. 2001, Jee et al. 2001). However, very little is known about the evasive mechanisms of the parasite in escaping the host's cellular defense mechanisms.

Activation of a respiratory burst of granulocytes and macrophages by invading microorganisms is an initial key process in the line of cellular defense against infection (Secombes 1996). Failure to generate this response leads to persistent life-threatening infection. Survival and establishment of systemic infections of 
scuticociliates despite intimate contact with activated components of their host's immune system suggests that scuticociliates are proactive in disrupting the initiation or expression of host immune responses. Therefore, this study was conducted to investigate the protective mechanisms of Uronema marinum against the toxic reactive oxygen intermediates (ROIs) produced by respiratory burst of olive flounder phagocytes.

\section{MATERIALS AND METHODS}

Isolation and culture of Uronema marinum. U. marinum were isolated asceptically from the brain of infected olive flounders Paralichthys olivaceus, inoculated into minimum essential medium (MEM; Sigma Chemical) containing 10\% foetal calf serum (Sigma) and then incubated at $20^{\circ} \mathrm{C}$. The ciliates were subcultured by inoculating about $1 \times 10^{5}$ cells into $200 \mathrm{ml}$ of the medium every $3 \mathrm{~d}$ for 3 mo.

Collection of Uronema marinum excretory-secretory (ES) products. The parasites were harvested from in vitro cultures and washed 3 times in Hanks' balanced salt solution (HBSS, Sigma) containing penicillin (100 $\mathrm{\mu g} \mathrm{ml^{-1 }}$, Sigma) and streptomycin $\left(100 \mathrm{U} \mathrm{ml}^{-1}\right.$, Sigma) by centrifugation at $1000 \times g$ for 5 min at $4^{\circ} \mathrm{C}$. ES products were collected by incubation of washed ciliates in HBSS at $20^{\circ} \mathrm{C}$ for $24 \mathrm{~h}$. The incubation medium was centrifuged at $1000 \times g$ for $10 \mathrm{~min}$ at $4^{\circ} \mathrm{C}$ and the supernatant was concentrated using Centricon-10 (Amicon) with a size exclusion of $10 \mathrm{kDa}$. Protein concentration was determined by the bicinchoninic acid assay (BCA; Smith et al. 1985). The concentrated ES products were stored in aliquots at $-70^{\circ} \mathrm{C}$.

Chemiluminescence (CL) assay. Five juvenile olive flounders were anaesthetised with tricaine methanesulfonate (MS222; Sigma). Head kidneys were asceptically removed and pooled, then pushed through nylon mesh with cold HBSS. The suspensions of leukocytes were immediately placed on a $34 / 51 \%$ Percoll (Sigma) density gradient, centrifuged at $400 \times g$ for $30 \mathrm{~min}$ at $4^{\circ} \mathrm{C}$. The interphase was collected and the cells were washed twice at $400 \times g$ for $5 \mathrm{~min}$ in HBSS containing heparin (10 units $\mathrm{ml}^{-1}$, Sigma), penicillin (100 $\mathrm{gg} \mathrm{ml}^{-1}$, Sigma) and streptomycin (100 $\mathrm{U} \mathrm{ml}^{-1}$, Sigma). The cell viability was examined with Trypan blue exclusion and was evaluated to be greater than $95 \%$. The leukocytes including granulocytes and macrophages were adjusted to $1 \times 10^{6}$ cells ml $^{-1} \mathrm{HBSS}$.

Zymosan (Sigma), a stimulant for phagocytosis, was incubated in a boiling water bath for $30 \mathrm{~min}$, washed 3 times and suspended in HBSS.

The ROIs produced by stimulated phagocytes were quantified using an automatic photoluminometer (Bio-
Orbit 1251). Each test cuvette contained $0.7 \mathrm{ml}$ luminol (Sigma) made according to the method of Scott \& Klesius (1981), $0.4 \mathrm{ml}$ phagocyte suspension, and $0.4 \mathrm{ml}$ of live parasites at 1:0.25, 1:0.5 and 1:1 phagocytes:parasites ratios or $0.4 \mathrm{ml}$ of ES products containing $0.3,0.15$ and $0.075 \mathrm{mg}$ protein $\mathrm{ml}^{-1} \mathrm{HBSS}$. In control cuvettes, $0.4 \mathrm{ml}$ HBSS was added instead of live parasites or ES products. To confirm the direct stimulatory effects of the parasites or ES products on phagocytes, CL responses were measured for $20 \mathrm{~min}$ prior to adding zymosan, then $0.3 \mathrm{ml}$ zymosan was added to each cuvette. All samples were analysed in triplicate. The measurements were made for $100 \mathrm{~min}$ and the light emission was recorded as $\mathrm{mV}$.

Viability of phagocytes. After CL assay, the number of viable phagocytes was counted in each cuvette by the Trypan blue exclusion test. In addition, freshly isolated phagocytes from the head kidneys of 3 juvenile olive flounders were exposed to ES products of the parasite, and then the viability and lysis of the phagocytes was examined under a light microscope.

Superoxide dismutase (SOD) and catalase activity of ES products. SOD was determined by the method of McCord \& Fridovich (1969) based on the inhibition of the reduction of ferricytochrome $\mathrm{C}$ in the presence of $\mathrm{O}_{2}^{-}$by superoxide dismutase. The reaction mixture consisted of $0.1 \mathrm{ml}$ of $0.3 \mathrm{mM}$ ferricytochrome C (Sigma), $0.1 \mathrm{ml}$ of $1.5 \mathrm{mM}$ xanthine (Sigma), $2.7 \mathrm{ml}$ of $0.05 \mathrm{M}$ potassium phosphate buffer at $\mathrm{pH} 7.8$ containing $0.1 \mathrm{mM}$ EDTA. The reaction was initiated by the addition of $0.1 \mathrm{ml}$ of diluted xanthine oxidase (Sigma, 25 unit). The cuvettes were incubated in a spectrophotometer at $20^{\circ} \mathrm{C}$ for $5 \mathrm{~min}$ and the increase in absorbance at $550 \mathrm{~nm}$ was measured for $3 \mathrm{~min}$. Several dilutions of xanthine oxidase were used to produce a rate of reduction of ferricytochrome $\mathrm{C}$ at $550 \mathrm{~nm}$ of 0.025 absorbance unit $\mathrm{min}^{-1}$. Addition of $0.1 \mathrm{ml}$ of different dilutions of SOD (Sigma) to the incubation mixture yielded an inhibition of ferricytochrome $\mathrm{C}$ reduction. Under these conditions, the amount of SOD (or ES products) required to inhibit the rate of reduction of cytochrome $\mathrm{C}$ by $50 \%$ is defined as 1 unit of activity.

Catalase activity was assayed by the method of Claiborne (1985). Briefly, the assay mixture consisted of $1.95 \mathrm{ml}$ of $0.05 \mathrm{M}$ phosphate buffer $(\mathrm{pH} 7.0), 1 \mathrm{ml}$ of $0.02 \mathrm{M}$ hydrogen peroxide (Sigma) and $0.05 \mathrm{ml}$ of ES products in a final volume of $3 \mathrm{ml}$. Change in absorbance was recorded at $240 \mathrm{~nm}$ for $5 \mathrm{~min}$. Catalase activity was calculated in terms of $\mathrm{nmol}_{2} \mathrm{O}_{2}$ consumed $\mathrm{min}^{-1} \mathrm{mg}^{-1}$ protein.

Statistical analysis. A 1-way analysis of variance (ANOVA), followed by a Tukey multiple-comparisons test was employed to evaluate the level of significance and the difference was considered significant when $\mathrm{p}<0.05$. 


\section{RESULTS}

Effect of live Uronema marinum and its ES products on CL responses of zymosan-stimulated phagocytes

Live Urenoma marinum inhibited (dose-dependently) CL responses of zymosan-stimulated phagocytes (Fig. 1). No significant reduction in CL response was observed compared to controls when phagocytes were incubated with $U$. marinum at a ratio of 1:0.25 phagocytes:ciliates. However, suppression of the CL response was significant when phagocytes were incubated with the ciliates at ratios of 1:0.5 and 1:1. Phagocytes incubated with the ciliates at a 1:1 ratio showed significantly lower CL response than phagocytes incubated with the ciliates at a 1:0.5 ratio. ES products from U. marinum similarly inhibited CL responses of zymosan-stimulated phagocytes in a dose-dependent manner (Fig. 1). The reduction of the CL response was significantly higher in phagocytes exposed to 0.15 and 0.3 $\mathrm{mg} \mathrm{ml}^{-1}$ of ES products compared to live ciliates or controls. Stimulation of phagocytes with live $U$. marinum or ES products alone did not elicit any CL responses.

\section{Effects of live Uronema marinum and its ES products on leucocyte viability}

After the CL assay, the number of viable phagocytes was significantly reduced in cultures incubated with live Uronema marinum at ratios of 1:0.5 and 1:1 phagocytes:ciliates or ES products with $0.3 \mathrm{mg}$ protein $\mathrm{ml}^{-1}$ compared to controls (Fig. 2). In a separate experiment, lysis of phagocytes by exposure to the same concentration of ES products was observed.

\section{Superoxide dismutase and catalase activity of ES products from Uronema marinum}

ES products from Uronema marinum showed considerably high antioxidative enzyme activities. SOD activity of ES products was $332.84 \pm 52.50 \mathrm{U} \mathrm{mg}^{-1}$ protein (mean $\pm \mathrm{SD}$, assayed in triplicate). Catalase activity in enzyme solutions prepared from ES products was $565.13 \pm 8.08 \mu \mathrm{mol} \mathrm{H}_{2} \mathrm{O}_{2}$ consumed $\mathrm{min}^{-1} \mathrm{mg}^{-1}$ protein (mean $\pm \mathrm{SD}$, assayed in triplicate).

\section{DISCUSSION}

In this study, both live Uronema marinum and its ES products had a negative and dose-dependent effect on the luminol-enhanced chemiluminescent response of zymosan-stimulated phagocytes of the olive flounder Par-

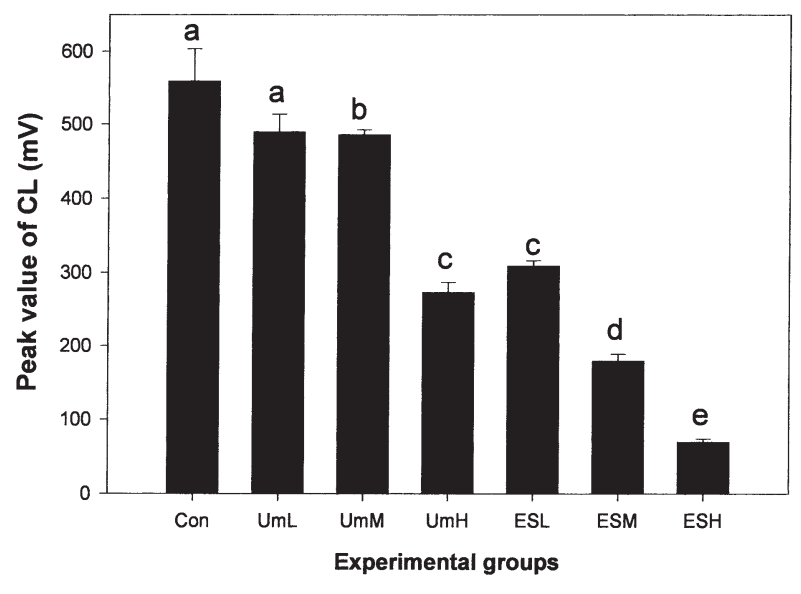

Fig. 1. Inhibition of zymosan-induced chemiluminescence (CL) in olive flounder Paralichthys olivaceus phagocytes by live Uronema marinum at ratios of 1:0.25 (UmL), 1:0.5 (UmM), and 1:1 (UmH) phagocytes:ciliates, or 0.075 (ESL), 0.15 (ESM), and $0.3(\mathrm{ESH}) \mathrm{mg}$ protein $\mathrm{ml}^{-1}$ Hanks' balanced salt solution (HBSS) of excretory-secretory (ES) products. In controls (Con), $0.4 \mathrm{ml}$ HBSS was added instead of live parasites or ES products. Mean peak values of CL + SD are shown. Different letters above bars denote statistically significant differences $(p<0.05)$ among groups

alichthys olivaceus. Similar results were found by Arbo et al. (1990), who reported that live Entamoeba histolytica, an extracellular protozoan parasite capable of invading the intestinal mucosa and spreading to other organs in humans, inhibits the respiratory burst of human polymorphonuclear leukocytes in a dose-dependent manner. Disruption of the respiratory burst of phagocytes has been documented for several intracellular protozoan parasites (Hall \& Joiner 1991, Jain et al. 1996, Panaro et al. 1996, Kim et al. 1998, Anderson 1999).

A significant reduction in the number of viable phagocytes after incubation with live ciliates and ES products

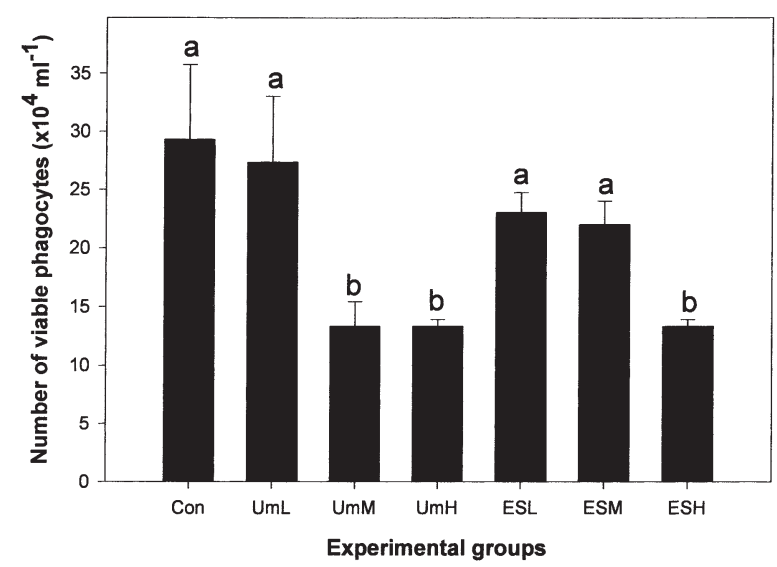

Fig. 2. Paralichthys olivaceus. Number of olive flounder phagocytes showing viability after chemiluminescence (CL) assay. Further details as in Fig. 1 
compared with controls, and lysis of phagocytes by ES products, indicate that Urenoma marinum secretes cytotoxic substances that can lyse olive flounder phagocytes. Cross \& Matthews (1993) reported that carp leukocytes which come into close contact with Ichthyophthirius multifiliis trophozoites are generally degraded, presumably due to lytic enzymes and/or metabolites released by the parasite. Cell infiltration around invading Entamoeba histolytica also leads to rapid lysis of inflammatory cells followed by tissue necrosis (MartínezPalomo et al. 1985, Shibayama et al. 1997).

The presence of superoxide dismutase and catalase activities in ES products of Uronema marinum indicates that these antioxidative enzymes play a role in quenching ROIs, which results in significantly diminished CL responses of zymosan-stimulated phagocytes. The toxic superoxide anion $\left(\mathrm{O}_{2}^{-}\right)$formed by the respiratory burst of phagocytes would be detoxified by enzymatic dismutation with SOD to $\mathrm{H}_{2} \mathrm{O}_{2}$, which then would be reduced to $\mathrm{H}_{2} \mathrm{O}$ by catalase. Therefore, $U$. marinum can protect itself against toxic oxygen metabolites through secretion of antioxidant enzymes, thus enabling the parasite to survive in the host.

In conclusion, Uronema marinum can protect itself against host phagocyte-mediated oxidative damage by destroying phagocytes and scavenging ROIs. These results may suggest a role of the ES products of $U$. marinum in virulence mechanisms, although further studies are necessary to confirm the release of $U$. marinum ES products in vivo and to determine its interaction with the host immune response.

Acknowledgements. This work was supported by grant no. R01-2000-000-00215 from the Basic Research Program of the Korea Science \& Engineering Foundation.

\section{LITERATURE CITED}

Anderson RS (1999) Perkinsus marinus secretory products modulate superoxide anion production by oyster (Crassostrea virginica) haemocytes. Fish Shellfish Immunol 9: $51-60$

Arbo A, Hoefsloot M, Ramirez A, Ignacio Santos J (1990) Entamobea histolytica inhibits the respiratory burst of polymorphonuclear leukocytes. Arch Invest Med 21(Suppl 1):57-61

Cheung PJ, Nigrelli RF, Ruggieri GD (1980) Studies on the morphology of Uronema marinum Dujardin (Ciliatea: Uronematidae) with a description of the histopatology of the infection in marine fishes. J Fish Dis 3:295-303

Claiborne A (1985) Catalase activity. In: Greenwald RA (ed) $\mathrm{CRC}$ handbook of methods in oxygen radical research. CRC Press, Boca Raton, FL, p 283-284

Cross ML, Matthews RA (1993) Localized leukocyte response to Ichthyophthirius multifiliis establishment in immune carp Cyprinus carpio L. Vet Immunol Immunopathol 38: 341-358

Dragesco A, Dragesco J, Coste F, Gasc C, Romestand B, Ray- mond J, Bouix G (1995) Philasterides dicentrarchi, n. sp. (Ciliophora, Scuticociliatida), a histophagous opportunistic parasite of Dicentrachus labrax (Linnaeus. 1758), a reared marine fish. Eur J Protistol 31:327-340

Dyková I, Figueras A (1994) Histopathological changes in turbot Scophthalmus maximus due to a histophagous ciliate. Dis Aquat Org 18:5-9

Gill PA, Calinan RB (1997) Ulcerative dermatitis associated with Uronema sp. infection of farmed sand whiting Sillago ciliata. Aust Vet J 75:357

Hall BF, Joiner KA (1991) Strategies of obligate intracellular parasites for evading host defences. Parasitol Today 7:A22-A27

Iglesias R, Paramá A, Alvarez MF, Leiro J, Fernández J, Sanmartín ML (2001) Philasterides dicentrarchi (Ciliophora, Scuticociliatida) as the causative agent of scuticociliatosis in farmed turbot Scophthalmus maximus in Galicia (NW Spain). Dis Aquat Org 46:47-55

Jain A, Tiwari V, Agarwal M (1996) Effect of Leishmania donovani antigens on superoxide action generation by mice polymorph in-vitro. Indian J Med Res 104:250-253

Jee BY, Kim YC, Park MS (2001) Morphology and biology of parasite responsible for scuticociliatosis of cultured olive flounder Paralichthys olivaceus. Dis Aquat Org 47:49-55

Kim JH, Ogawa K, Wakabayashi H (1998) Respiratory burst assay of head kidney macrophages of ayu, Plecoglossus altivelis, stimulated with Glugea plecoglossi (Protozoa: Microspora) spores. J Parasitol 84:552-556

Martínez-Palomo A, González-Robles A, Chávez B, Orozco E, Fernández-Castelo S, Cervantes A (1985) Structural bases of the cytolytic mechanisms of Entamoeba histolytica. J Protozool 32:166-175

McCord EF, Fridovich I (1969) Superoxide dismutase. An enzymic function for erythrocuprein (hemocuprein). J Biol Chem 244:6049-6055

Munday BL, O'Donoghue PJ, Watts M, Rough K, Hawkesford $\mathrm{T}$ (1997) Fatal encephalitis due to the scuticociliate Uronema nigricans in sea-caged, southern bluefin tuna Thunnus maccoyii. Dis Aquat Org 30:17-25

Panaro MA, Puccini V, Faliero SM, Marzio R, Marangi A, Lisi S, Brandonisio O (1996) Leishmania donovani lipophosphoglycan (LPG) inhibits respiratory burst and chemotaxis of dog phagocytes. Microbiologica (Pavia) 19:107-112

Scott AL, Klesius PH (1981) Chemiluminescence: a novel analysis of phagocytosis in fish. Dev Biol Stand 49: 243-254

Secombes CJ (1996) The nonspecific immune system: cellular defenses. In: Iwama G, Nakanishi T (eds) The fish immune system-organism, pathogen, and environment. Academic Press, New York, p 63-103

Shibayama M, Navarro-Garcia F, López-Revilla R, MartínezPalomo A, Tsutsumi V (1997) In vivo and in vitro experimental intestinal amebiasis in Mongolian gerbils (Meriones unguiculatus). Parasitol Res 83:170-176

Smith PK, Krohn RI, Hermanson GT, Mallia AK and 6 others (1985) Measurement of protein using bicinchoninic acid. Anal Biochem 150:76-85

Sterud E, Hansen MK, Mo TA (2000) Systemic infecion with Uronema-like ciliates in farmed turbot, Scophtalmus maximus (L.). J Fish Dis 23:33-37

Thompson CL Jr, Moewus L (1964) Miamiensis avidus n. g. n. s., a marine facultative parasite in the ciliate order Hymenostomatida. J Protozool 11:378-381

Yoshinaga T, Nakazoe J (1993) Isolation and in vitro cultivation of an unidentified ciliate causing scuticociliatosis in Japanese flounder (Paralichthys olivaceus). Fish Pathol (Gyobyo Kenkyu) 28:131-134

Submitted: November 1, 2001; Accepted: June 20, 2002

Proofs received from author(s): November 4, 2002 